\title{
Oral contraceptive and reproductive risk factors for ovarian cancer within sisters in the breast cancer family registry
}

\author{
J S Ferris ${ }^{1}$, M B Daly ${ }^{2}$, S S Buys ${ }^{3}$, J M Genkinger ${ }^{1}$, Y Liao $^{1}$ and M B Terry ${ }^{\star}, 1,4$ \\ ${ }^{1}$ Department of Epidemiology, Columbia University, Mailman School of Public Health, New York, NY 10032, USA; ${ }^{2}$ Fox Chase \\ Cancer Center, 333 Cottman Avenue, Philadelphia, PA 19111-2497, USA; ${ }^{3}$ Huntsman Cancer Institute, University of Utah Health \\ Sciences Center, Salt Lake City, UT 84112, USA and ${ }^{4}$ Herbert Irving Comprehensive Cancer Center, Columbia University, New \\ York, NY 10032, USA
}

Background: Oral contraceptive use has been consistently associated with a reduced risk of ovarian cancer in unrelated, average risk women; however little data exist on whether this benefit extends to higher risk women from cancer families. To examine this, we conducted family-based analyses using the Breast Cancer Family Registry.

Methods: We used generalised estimating equations to obtain the population average effect across all families ( $n=389$ cases, $n=5643$ controls) and conditional logistic regression to examine within-family differences in a subset with at least two sisters discordant on ovarian cancer status ( $n=109$ cases, $n=149$ unaffected sister controls).

Results: In the multivariable generalised estimating equation model there was a reduced risk of ovarian cancer for ever use of oral contraceptives compared with never use $(\mathrm{OR}=0.58,95 \% \mathrm{Cl}: 0.37,0.91)$, and in the conditional logistic model there was a similar inverse association; however, it was not statistically significant ( $\mathrm{OR}=0.52,95 \% \mathrm{Cl}: 0.23,1.17)$. We examined this association by BRCA1/2 status and observed a statistically significant reduced risk in the non-carriers only.

Conclusion: We observed a decreased risk of ovarian cancer with oral contraceptive use supporting that this association observed in unrelated women extends to related women at higher risk.

Ovarian cancer, diagnosed in over 22000 women in the United States annually, has a low 5-year survival rate at $44 \%$ with no effective population screening methods (Buys et al, 2011; ACS, 2012). Women are at substantially higher risk if they have a mutation in BRCA1/2 with a $40-50 \%$ increased risk for BRCA1 carriers and a $20-30 \%$ increased risk for BRCA2 carriers (Russo et al, 2009). However, only $\sim 15 \%$ of all ovarian cancer cases (Pal et al, 2005; Hyman and Spriggs, 2012) and $<50 \%$ of all familial ovarian cancer cases (Ramus et al, 2007) are thought to be attributed to mutations in $B R C A 1 / 2$. Having one affected first-degree relative increases a woman's risk of ovarian cancer three-fold and having multiple affected family members (first or second degree) increases a woman's risk up to 11-fold (Stratton et al, 1998).
Thus, women with a family history of ovarian cancer are at a much higher risk of ovarian cancer, although the majority of these women with a family history do not have a mutation in BRCA1/2.

Oral contraceptive use has been consistently shown to reduce the risk of ovarian cancer (Collaborative Group on Epidemiological Studies of Ovarian Cancer et al, 2008) and may be a more viable chemopreventive option for women at high risk than bilateral prophylactic oophorectomy, particularly for women in their childbearing years (Rice, 2010). In a meta-analysis of 45 epidemiological studies, ever use of oral contraceptives was found to reduce the risk of ovarian cancer by $27 \%$ for all studies, with further reductions up to $58 \%$ with 15 years or more of use (Collaborative Group on Epidemiological Studies of Ovarian Cancer et al, 2008). This 
inverse association with oral contraceptives has also been seen in women at high risk of ovarian cancer with known mutations in the $B R C A 1 / 2$ genes (Runnebaum et al, 2001; Whittemore et al, 2004; Gronwald et al, 2006; McLaughlin et al, 2007; Antoniou et al, 2009). A recent meta-analysis of $B R C A 1$ and $B R C A 2$ mutation carriers found a summary relative risk of $0.50(0.33,0.75)$ for ever users of oral contraceptives vs never users (Iodice et al, 2010). The analyses, however, were either exclusively or primarily conducted within unrelated individuals. The question of whether oral contraceptives also prevent ovarian cancer within families is an important question guiding clinical management for many women from cancer families.

Pregnancy has also been found to be associated with a lower risk of ovarian cancer in average risk women, with parous women having a $24-53 \%$ lower risk compared with nulliparous women and each additional full-term pregnancy providing a further reduction in risk (Gwinn et al, 1990; Negri et al, 1991; Whittemore et al, 1992; Risch et al, 1994). In addition, breastfeeding has been shown to lower the risk of ovarian cancer with women who ever breastfed having a 19-40\% lower risk compared with women who never breastfed (Gwinn et al, 1990; Whittemore et al, 1992; Risch et al, 1994). When assessing parity in BRCA1/2 mutation carriers, some studies have reported no association with ovarian cancer (Gronwald et al, 2006), whereas others have reported either positive associations (Antoniou et al, 2009) or inverse associations (Modan et al, 2001; McGuire et al, 2004; McLaughlin et al, 2007).

Risk factors that have been shown to consistently influence risk for average risk women at the population level are sometimes not observed to influence risk within higher risk women. For example, alcohol consumption has consistently been associated with breast cancer risk in average risk women, but there is little-to-no strong evidence that it influences risk in high risk women and families (McGuire et al, 2006; Terry et al, 2007; McDonald et al, 2013). Therefore, given the lack of empirical evidence for clinicians to advise a woman who comes into the clinic wanting to know what she can do to lower her risk of ovarian cancer if she has a sister affected with ovarian cancer, we undertook a family-based analysis to examine the association between oral contraceptive use, parity, breastfeeding and ovarian cancer risk.

\section{MATERIALS AND METHODS}

Subjects. We included participants from the three clinic-based sites of the Breast Cancer Family Registry (BCFR) (New York, Philadelphia and Utah) who had detailed information on ovarian cancer incidence within families. Details of recruitment and methodology of the BCFR are published elsewhere (John et al, 2004; Kennedy et al, 2005; Shen et al, 2007; Terry et al, 2007; Machella et al, 2008; Yazici et al, 2009; Zipprich et al, 2009; Wu et al, 2011; Delgado-Cruzata et al, 2012; Shen et al, 2012; Wu et al, 2012). In brief, the New York site of the BCFR recruited affected and unaffected probands with a family history of breast and ovarian cancer from local hospitals, organisations and breast cancer support groups throughout the community. The Philadelphia site of the BCFR recruited affected probands with a family

Table 1. Demographic, reproductive and behavioural differences between ovarian cancer cases and controls in the Breast Cancer Family Registry

\begin{tabular}{|c|c|c|c|c|}
\hline & $\begin{array}{l}\text { Ovarian cancer cases with } \\
\text { unaffected sisters }(n=109)\end{array}$ & $\begin{array}{l}\text { Unaffected sister } \\
\text { controls }(n=149)\end{array}$ & $\begin{array}{l}\text { All ovarian cancer } \\
\text { cases }(n=389)\end{array}$ & All controls $(n=5643)$ \\
\hline Characteristic & Mean (s.d.)/n (\%) & Mean (s.d.)/n (\%) & Mean (s.d.)/n (\%) & Mean (s.d.)/n (\%) \\
\hline Age (years) & $48.4(12.1)$ & $46.3(11.1)$ & $51.9(12.3)$ & $47.9(16.0)$ \\
\hline \multicolumn{5}{|l|}{ Race (\%) } \\
\hline White & $91(83.5)$ & $124(83.2)$ & $336(86.4)$ & $4493(79.6)$ \\
\hline Other & $17(15.6)$ & 25 (16.8) & $51(13.1)$ & 1124 (19.9) \\
\hline Age at menarche (years) & $12.5(1.4)$ & $12.9(1.5)$ & $12.5(1.6)$ & $12.6(1.5)$ \\
\hline Height (m) & $1.6(0.1)$ & $1.6(0.1)$ & $1.6(0.1)$ & $1.6(0.1)$ \\
\hline BMI $\left(\mathrm{kg} \mathrm{m}^{-2}\right)$ & $25.8(6.3)$ & $25.5(5.7)$ & $25.6(5.6)$ & $25.3(5.4)$ \\
\hline \multicolumn{5}{|l|}{ Cigarette use (\%) } \\
\hline Ever & $29(26.6)$ & $42(28.2)$ & $142(36.5)$ & $2089(37.0)$ \\
\hline Never & $78(71.6)$ & $104(69.8)$ & $241(62.0)$ & $3498(62.0)$ \\
\hline \multicolumn{5}{|l|}{ Parity (\%) } \\
\hline 0 & $25(22.9)$ & $39(26.2)$ & $56(14.4)$ & $1403(24.9)$ \\
\hline 1 & $10(9.2)$ & $12(8.1)$ & $32(8.2)$ & $714(12.7)$ \\
\hline$\geqslant 2$ & $74(67.9)$ & $97(65.1)$ & $301(77.4)$ & $3511(62.2)$ \\
\hline Age at first birth (years) & $24.5(4.7)$ & $24.3(5.1)$ & $24.4(4.4)$ & $25.3(5.1)$ \\
\hline Age at last birth (years) & $30.4(5.6)$ & $30.8(5.1)$ & $30.7(5.1)$ & $30.7(5.3)$ \\
\hline \multicolumn{5}{|l|}{ Breastfeeding (\%) } \\
\hline Yes & $44(40.4)$ & $61(40.9)$ & $171(44.0)$ & $2686(47.6)$ \\
\hline No & $56(51.4)$ & $74(49.7)$ & $157(40.4)$ & $2603(46.1)$ \\
\hline \multicolumn{5}{|l|}{ Oral contraceptive use (\%) } \\
\hline Yes & $47(43.1)$ & $76(51.0)$ & $129(33.2)$ & $3328(59.0)$ \\
\hline No & $55(50.5)$ & $61(40.9)$ & $224(57.6)$ & $2099(37.2)$ \\
\hline Duration of Oral contraceptive use (year) & $3.4(5.0)$ & $5.0(4.7)$ & $4.6(5.5)$ & $5.0(5.0)$ \\
\hline Age at first oral contraceptive use (year) & $22.4(5.2)$ & $22.8(5.5)$ & $23.0(6.3)$ & $22.1(5.4)$ \\
\hline
\end{tabular}


history of breast and/or ovarian cancer from the Fox Chase Family Risk Assessment Programme and Cooper Hospital/University Medical Center in Camden. The Utah site of the BCFR recruited families with three or more cases of breast or ovarian cancer from local clinicians and the Family Cancer Assessment Clinic at Huntsman Cancer Institute. Institutional review boards at each of the three sites approved the study protocols, and all participants provided written informed consent at the time of enrolment. The eligibility criteria for each site included being a male with breast cancer, being a female diagnosed with breast cancer at a young age, being a female diagnosed with breast and ovarian cancer at any age, having multiple affected relatives with breast or ovarian cancer or being a BRCA1/2 mutation carrier (John et al, 2004; Neuhausen et al, 2009). Overall, there were 2375 families from the three clinicbased sites, and 101 families who have at least two sisters discordant for ovarian cancer status. All sisters were included in the analyses.

Questionnaires. We administered an epidemiologic questionnaire to participants at baseline that collected information on demographics, environment and behaviour, such as race/ethnicity, radiation exposure, height, weight, physical activity, smoking and alcohol consumption, reproductive information including menstrual and pregnancy history, breastfeeding and hormone use, history of breast and ovarian cancer and breast and ovarian procedures. We administered proxy questionnaires to relatives of deceased participants (13.7\% of the participants) (John et al, 2004).

BRCA1 and BRCA2 mutation testing. We tested probands affected with breast and/or ovarian cancer for BRCA1 and BRCA2 mutations. If the proband was unaffected, then we tested the youngest breast or ovarian cancer case in the family with an available blood sample. Individual sites and Myriad Genetic
Laboratories conducted the genetic tests using full sequence analysis. If we found a deleterious mutation, we then offered testing for the same mutation to other family members with an available blood sample (John et al, 2004; Neuhausen et al, 2009).

Statistical analysis. We used a within-family conditional logistic regression model to assess the association between exposures and ovarian cancer using only families with at least two sisters discordant on ovarian cancer status. All sisters were included in the analysis. We used conditional logistic regression methods, which allows for N:M matching, as well as through generalised estimating equation approaches (GEE). To examine this association across the high risk spectrum, we used GEE that evaluate the association between exposures and ovarian cancer as a population average effect across all families using two samples: (1) cases with sister controls and (2) all cases and all controls including families with only one sister. The first GEE model allowed us to compare results of the same sample between two different statistical models (conditional logistic vs GEE), and the second GEE model gave us a larger sample size and more power to assess these associations by including all cases, even singleton cases, and all controls.

We evaluated oral contraceptive use by assessing ever $v s$ never use. Duration of oral contraceptive use was evaluated using the following categories: 0.5 to $<3$ years, 3 to $<6$ years, $\geqslant 6$ years, with never use as the reference group. Age at first oral contraceptive use was evaluated using the following categories: $<20,20-25,>25$ years, with never use as the reference group. We assessed parity using the following categories: $0,1, \geqslant 2$ live births, with nulliparity as the reference group. We assessed age at first parity using the following categories: $<22,22-27,>27$ years, with nulliparity as the reference group. We evaluated breastfeeding as ever breastfed $v s$ never breastfed.

\begin{tabular}{|c|c|c|c|c|c|}
\hline & \multicolumn{2}{|c|}{ Conditional logistic } & \multicolumn{2}{|c|}{ GEE } & GEE \\
\hline & \multicolumn{2}{|c|}{ Cases with unaffected sister controls } & \multicolumn{2}{|c|}{ Cases with unaffected sister controls } & All cases and all controls \\
\hline & Age-adjusted model & Multivariable model $^{a}$ & Age-adjusted model & Multivariable model $^{\mathbf{b}}$ & Multivariable model ${ }^{c}$ \\
\hline & OR $(95 \% \mathrm{Cl})$ & OR $(95 \% \mathrm{Cl})$ & OR $(95 \% \mathrm{Cl})$ & OR $(95 \% \mathrm{Cl})$ & OR $(95 \% \mathrm{Cl})$ \\
\hline \multicolumn{6}{|c|}{ Oral contraceptive use } \\
\hline $\begin{array}{l}\text { Never } \\
\text { Ever }\end{array}$ & $\begin{array}{c}\text { Ref } \\
0.51(0.23,1.15)\end{array}$ & $\begin{array}{c}\text { Ref } \\
0.52(0.23,1.17)\end{array}$ & $\begin{array}{c}\text { Ref } \\
0.71(0.47,1.06)\end{array}$ & $\begin{array}{c}\text { Ref } \\
0.58(0.37,0.91)\end{array}$ & $\begin{array}{c}\text { Ref } \\
0.35(0.27,0.45)\end{array}$ \\
\hline \multicolumn{6}{|c|}{ Duration of oral contraceptive use (years) } \\
\hline $\begin{array}{l}0 \\
<3 \\
3 \text { to }<6 \\
\geqslant 6 \\
P \text {-value for trend }\end{array}$ & $\begin{array}{c}\text { Ref } \\
0.77(0.32,1.85) \\
0.18(0.04,0.88) \\
0.26(0.08,0.84) \\
<0.01\end{array}$ & $\begin{array}{c}\text { Ref } \\
0.85(0.34,2.10) \\
0.19(0.04,0.90) \\
0.26(0.08,0.83) \\
<0.01\end{array}$ & $\begin{array}{c}\text { Ref } \\
1.16(0.68,1.97) \\
0.30(0.10,0.88) \\
0.44(0.23,0.84) \\
<0.01\end{array}$ & $\begin{array}{c}\text { Ref } \\
0.99(0.54,1.80) \\
0.27(0.09,0.83) \\
0.33(0.16,0.67) \\
<0.01\end{array}$ & $\begin{array}{c}\text { Ref } \\
0.41(0.30,0.55) \\
0.23(0.15,0.38) \\
0.34(0.24,0.49) \\
<0.01\end{array}$ \\
\hline \multicolumn{6}{|c|}{ Age at first oral contraceptive use (years) } \\
\hline $\begin{array}{l}\text { Never } \\
<20 \\
20-25 \\
>25 \\
P-\text { value for trend }\end{array}$ & $\begin{array}{c}\text { Ref } \\
0.66(0.18,2.47) \\
0.20(0.06,0.68) \\
0.61(0.19,1.96) \\
0.07\end{array}$ & $\begin{array}{c}\text { Ref } \\
0.68(0.18,2.56) \\
0.21(0.06,0.71) \\
0.61(0.19,1.96) \\
0.07\end{array}$ & $\begin{array}{c}\text { Ref } \\
0.87(0.48,1.57) \\
0.45(0.24,0.82) \\
0.66(0.28,1.57) \\
0.03\end{array}$ & $\begin{array}{c}\text { Ref } \\
0.71(0.37,1.39) \\
0.35(0.18,0.66) \\
0.55(0.23,1.30) \\
<0.01\end{array}$ & $\begin{array}{c}\text { Ref } \\
0.26(0.18,0.39) \\
0.26(0.19,0.37) \\
0.46(0.31,0.69) \\
<0.01\end{array}$ \\
\hline
\end{tabular}


Including the main exposure variables described above (oral contraceptive use, parity and breastfeeding), we assessed the following variables as potential confounders: age, race/ethnicity, hormone replacement therapy use, age at last birth, age at menarche, body mass index $\left(\mathrm{kg} \mathrm{m}^{-2}\right)$, height $(\mathrm{m})$, cigarette use, and alcohol consumption. We evaluated these potential confounders using the $10 \%$ criterion: any variable that changed the parameter estimate for the association between the main exposure variable and ovarian cancer by more than $10 \%$ remained in the final parsimonious model. We truncated all variables in order to capture the appropriate exposure period before diagnosis. For cases, we defined the reference age as 1 year before diagnosis. We truncated all variables for sister controls based on the reference age of the case sister.

We conducted the following sensitivity analyses to examine the robustness of our results: (1) excluded any participants diagnosed with breast cancer before the ovarian cancer for cases and before the reference age for controls, (2) excluded proxy data and (3) restricted all analyses to only cases of ovarian cancer that were pathologically confirmed. In addition, we assessed effect measure modification by $B R C A 1 / 2$ status. Using the GEE model in all cases and controls, we stratified this analysis by BRCA1/2 status to examine the association between ever $v s$ never oral contraceptive use and ovarian cancer in those with a known mutation in either BRCA1 or BRCA2 and those with no known mutations. We conducted all statistical analyses using SAS version 9.2 (Cary, NC, USA).

\section{RESULTS}

Table 1 shows demographic, reproductive and behavioural differences between ovarian cancer cases and controls for each sample used in the statistical models. Cases were less likely to be nulliparous compared with controls but were otherwise similar. Table 2 shows the results for oral contraceptives. In the withinfamily conditional logistic model, there was a non-significant reduced risk of ovarian cancer for ever use of oral contraceptives compared with never use; however, in the GEE models this association was statistically significant. Comparing ever use of oral contraceptives with never use, the risk of ovarian cancer was 0.58 (95\% CI: $0.37,0.91)$ in the model with sister controls and 0.35 (95\% CI: $0.27,0.45)$ in the model with all cases and controls. All models showed a statistically significant inverse trend for years of oral contraceptive use with the greatest reduction seen in those who used oral contraceptives for 3 years or more. In addition, all models showed the greatest reduction in risk for those who initiated use between the ages of 20-25 years. Figure 1 shows the oral contraceptive results stratified by $B R C A 1 / 2$ mutation status. In both the age-adjusted and multivariable models, the inverse association between oral contraceptives and ovarian cancer was stronger and only statistically significant in those who were $B R C A 1 / 2$ mutation negative compared with those who were $B R C A 1 / 2$ mutation positive. When we tested this formally, there was a statistically significant multiplicative interaction between oral contraceptive use and BRCA1/2 mutation status $(P<0.01)$.

Table 3 shows the results of parity and breastfeeding. In the model with all cases and all controls, there was a statistically significant increased risk of ovarian cancer among women with two or more children compared with nulliparous women $(\mathrm{OR}=2.30,95 \% \mathrm{CI}: 1.52,3.48)$. We further assessed whether this was a transient increase in risk by examining women who had more recently given birth $(<10$ years) and women who had not recently given birth ( $\geqslant 10$ years). Compared with nulliparous women, there was only a statistically significant increased risk of ovarian cancer in women whose time since last birth was 10 years or greater (data not shown). In all other models, there was a

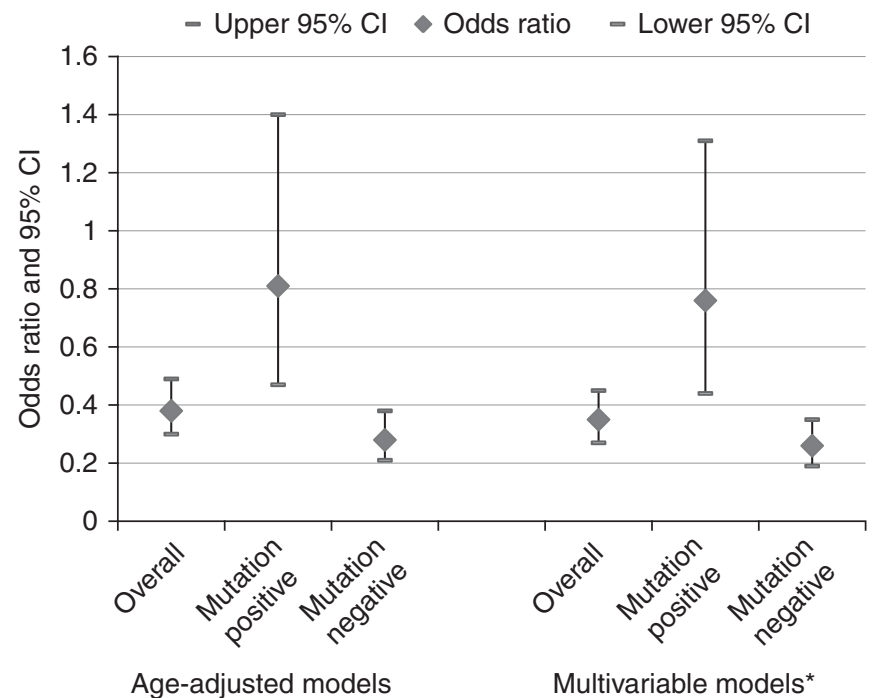

Figure 1. Risk of ovarian cancer by oral contraceptive use among all cases and controls by BRCA1/2 mutation status among women in the Breast Cancer Family Registry (Mutation negative imputed). *Adjusted for age, race, parity. Age-adjusted models: overall: $n=5780$, case mutation positive: $n=76$, case mutation negative: $n=277$, control mutation positive: $n=566$, control mutation negative: $n=4861$. Multivariable models: overall: $n=5749$, case mutation positive: $n=75$, case mutation negative: $n=276$, control mutation positive: $n=564$, control mutation negative: $n=4834$.

suggestion of an increased risk of ovarian cancer in women with one child compared with nulliparous women, but these results did not reach statistical significance. There was no association between ovarian cancer and either age at first birth or breastfeeding.

When we performed the three sensitivity analyses excluding cases and controls with previous breast cancer, excluding proxy data and excluding non-pathologically confirmed cases of ovarian cancer, our overall inferences of an inverse association between oral contraceptives and ovarian cancer and a positive association between parity and ovarian cancer remained (data not shown).

\section{DISCUSSION}

Although familial ovarian cancers make up a small percent of all ovarian cancers, women who come from families with breast and ovarian cancer are at a much higher risk of developing ovarian cancer than the general population. Given the absence of symptoms in early-stage disease and lack of effective screening, ovarian cancer is typically diagnosed at late stages resulting in a low survival rate. As prophylactic oophorectomy may not be a viable option for many women, it is crucial to identify other preventive factors for high risk women. There are two factors, oral contraceptive use and parity, that have consistently been shown to be associated with a reduced risk of ovarian cancer in average risk women; however, in higher risk women this consistency has only remained for oral contraceptive use, while parity has been less clear (Modan et al, 2001; McGuire et al, 2004; Gronwald et al, 2006; McLaughlin et al, 2007; Antoniou et al, 2009).

We found that ever use of oral contraceptives reduced the risk of ovarian cancer within families and that the effect size was robust to the statistical model. When we examined this association by $B R C A 1 / 2$ mutation status, we only observed a statistically significant reduced risk in the non-carriers. We were limited, 


\begin{tabular}{|c|c|c|c|c|c|}
\hline & \multicolumn{2}{|c|}{ Conditional logistic } & \multicolumn{2}{|c|}{ GEE } & GEE \\
\hline & \multicolumn{2}{|c|}{ Cases with unaffected sister controls } & \multicolumn{2}{|c|}{ Cases with unaffected sister controls } & \multirow{2}{*}{$\begin{array}{c}\text { All cases and all controls } \\
\text { Multivariable model }^{\mathrm{c}}\end{array}$} \\
\hline & Age-adjusted model & Multivariable model $^{a}$ & Age-adjusted model & Multivariable model ${ }^{b}$ & \\
\hline & OR $(95 \% \mathrm{Cl})$ & OR $(95 \% \mathrm{Cl})$ & OR $(95 \% \mathrm{Cl})$ & OR $(95 \% \mathrm{Cl})$ & OR $(95 \% \mathrm{Cl})$ \\
\hline \multicolumn{6}{|c|}{ No. of full-term births } \\
\hline $\begin{array}{l}0 \\
1 \\
\geqslant 2\end{array}$ & $\begin{array}{c}\text { Ref } \\
1.58(0.45,5.53) \\
0.97(0.35,2.65)\end{array}$ & $\begin{array}{c}\text { Ref } \\
1.23(0.23,6.45) \\
0.50(0.12,2.12)\end{array}$ & $\begin{array}{c}\text { Ref } \\
1.52(0.53,4.42) \\
1.21(0.63,2.34)\end{array}$ & $\begin{array}{c}\text { Ref } \\
1.21(0.30,4.97) \\
0.96(0.40,2.27)\end{array}$ & $\begin{array}{c}\text { Ref } \\
1.64(0.96,2.81) \\
2.30(1.52,3.48)\end{array}$ \\
\hline \multicolumn{6}{|c|}{ Age at first birth (years) } \\
\hline $\begin{array}{l}\text { Nulliparous } \\
<22 \\
22-27 \\
>27\end{array}$ & $\begin{array}{c}\text { Ref } \\
0.97(0.31,3.11) \\
1.20(0.41,3.46) \\
1.05(0.31,3.56)\end{array}$ & $\begin{array}{c}\operatorname{Ref} \\
0.62(0.13,3.01) \\
0.67(0.15,2.92) \\
0.70(0.14,3.37)\end{array}$ & $\begin{array}{c}\text { Ref } \\
1.27(0.61,2.62) \\
1.38(0.67,2.87) \\
1.04(0.48,2.25)\end{array}$ & $\begin{array}{c}\operatorname{Ref} \\
0.82(0.31,2.15) \\
1.00(0.40,2.55) \\
1.22(0.42,3.52)\end{array}$ & $\begin{array}{c}\text { Ref } \\
2.72(1.76,4.20) \\
2.30(1.49,3.53) \\
1.40(0.86,2.27)\end{array}$ \\
\hline \multicolumn{6}{|c|}{ Breastfeeding } \\
\hline $\begin{array}{l}\text { Never } \\
\text { Ever }\end{array}$ & $\begin{array}{c}\text { Ref } \\
0.77(0.31,1.94)\end{array}$ & $\begin{array}{c}\text { Ref } \\
1.72(0.54,5.43)\end{array}$ & $\begin{array}{c}\text { Ref } \\
0.86(0.50,1.49)\end{array}$ & $\begin{array}{c}\text { Ref } \\
1.57(0.77,3.20)\end{array}$ & $\begin{array}{c}\text { Ref } \\
0.81(0.61,1.06)\end{array}$ \\
\hline $\begin{array}{l}\text { Abbreviations: } \\
{ }^{\text {a Adjusted for }} \\
{ }^{\text {b Adjusted for }} \\
{ }^{c} \text { Adjusted for }\end{array}$ & $\begin{array}{l}=\text { confidence interval; GEE }=\mathrm{ge} \\
\text { breastfeeding, age at menarc } \\
\text { oral contraceptive use, age at } \\
\text { oral contraceptive use, age at }\end{array}$ & $\begin{array}{l}\text { alised estimating equation al } \\
\text { height. } \\
\text { st birth, age at last birth, brea } \\
\text { it birth, breastfeeding. }\end{array}$ & $\begin{array}{l}\text { ches; } \mathrm{OR}=\text { odds ratio. } \\
\text { ding, age at menarche, heig }\end{array}$ & & \\
\hline
\end{tabular}

however, in the number of carriers in this study, and one recent meta-analysis of 18 studies found that oral contraceptives significantly reduced the risk of ovarian cancer in BRCA1/2 mutation carriers (Iodice et al, 2010). Narod et al (1998) conducted a case-control study of oral contraceptive use and ovarian cancer using sister controls. They observed a $50 \%$ reduced risk of ovarian cancer for ever use of oral contraceptives compared with never use and up to a $60 \%$ reduced risk of ovarian cancer with six or more years of use. When they restricted their analysis to only cases and controls with a confirmed BRCA1/2 mutation, they observed a $60 \%$ reduced risk of ovarian cancer among ever users and a $70 \%$ reduced risk of ovarian cancer with six or more years of use. In our study, we observed a similarly large reduction in risk. We observed a significant inverse trend for the duration of oral contraceptive use and risk of ovarian cancer, and the greatest reduction in risk was seen for those who used oral contraceptives for three or more years.

Emerging research suggests that the fallopian tube is the site of origin of pelvic serous ovarian carcinomas (Crum et al, 2007; Reitsma et al, 2012) and that chronic inflammation, which leads to rapid cell division and DNA replication errors, may be a precursor to ovarian cancer (Salvador et al, 2009). Oral contraceptives are known to cause a number of changes in the body: thickening of the cervical mucosa, thinning of the endometrial lining, reduced menstrual flow, reduced fallopian contractility and reduced amount of cilia in the fimbria. These changes caused by oral contraceptives may lead to a reduced risk of ovarian cancer by preventing movement of infections and menstrual inflammatory mediators through the cervix and fallopian tubes (Salvador et al, 2009). The fallopian tube hypothesis also supports a protective effect of parity that leads to a thickening of the cervical mucus and a cessation of menstrual flow.

The increased risk from parity that we observed, while not supportive of the fallopian tube hypothesis, is consistent with emerging data on high risk women. For example, a study of BRCA1/2 mutation carriers by Antoniou et al (2009) found a nonsignificant increased risk of ovarian cancer for parous compared with nulliparous women, and they also found that women with one full-term pregnancy had a statistically significant increased risk of ovarian cancer compared with nulliparous women. They also found no association between ever breastfed or duration of breastfeeding and ovarian cancer in BRCA1/2 mutation carriers (Antoniou et al, 2009). McLaughlin et al (2007) found parity to be associated with an increased risk of ovarian cancer in BRCA2 mutation carriers, but with a reduced risk of ovarian cancer in BRCA1 mutation carriers. They also found breastfeeding to be significantly associated with a reduced risk of ovarian cancer in BRCA1 mutation carriers, but the result for BRCA2 mutation carriers was not statistically significant (McLaughlin et al, 2007). Another smaller study of BRCA1 mutation carriers observed a non-significant reduced risk of ovarian cancer in parous women compared with nulliparous (McGuire et al, 2004). Despite the consistent findings of a reduced risk of ovarian cancer with parity and breastfeeding in average risk women, the recent work in BRCA1/2 mutation carriers has not supported this in high risk women. Our results within high risk families further support the idea that parity and breastfeeding may have differential effects in high risk and average risk women.

Limited research has been done to examine established and suspected risk factors for ovarian cancer within families. Specifically, our results help address a gap in the literature for clinicians regarding modifiable factors that they can recommend to women who have a sister affected with ovarian cancer, which will reduce their risk of ovarian cancer. In addition to our withinfamily findings, our GEE results support the use of OCs for women across the high risk spectrum. Since women at high risk of ovarian cancer are also at an increased risk of breast cancer, some clinicians may be hesitant to recommend oral 
contraceptives to their patients; however, the evidence to date regarding breast cancer risk in carriers has not been consistent. A recent meta-analysis assessed the association between oral contraceptives and risk of breast cancer in BRCA1/2 mutation carriers, and the majority of case-control and case-case studies did not support an increased risk (Cibula et al, 2011). There was a suggestion of an increased risk of breast cancer in the cohort studies, but larger prospective studies are needed to definitively address this question.

Family-based studies have the ability to control for some confounding factors and factors that could create selection bias that pose a challenge to studies of unrelated individuals. Specifically, the conditional logistic models were able to control for some shared genetic and environmental factors that are more difficult to measure, and therefore control for, in studies of unrelated individuals. In addition, oral contraceptive use (Oakley et al, 1991; Spangler et al, 2012) and number of children (reviewed in (Harlow and Linet, 1989)) have been shown to be reliability reported; therefore, we expect any information bias to be minimal. The baseline questionnaire did not collect information on tubal ligation; hence, we were unable to assess this variable in the analysis. However, data show that tubal ligation rates have decreased from 14.9 per 1000 unsterilised women in 1977 to 12.2 per 1000 unsterilised women in 2006 (Chan and Westhoff, 2010). Therefore, it is likely that only a small proportion of our cohort had tubal ligation, which would not have had substantially influenced our results.

In conclusion, we found that oral contraceptives reduce the risk of ovarian cancer in related women at high risk, and, specifically, women who have a sister with ovarian cancer. This finding is consistent with the literature in unrelated, average risk women. In contrast, our study suggests that the reduced risk from parity and breastfeeding in average risk women may not extend to higher risk women. Our findings suggest that even within high risk families there may be potential modifiable factors that can influence risk of this highly fatal disease.

\section{ACKNOWLEDGEMENTS}

We thank the participants of the Breast Cancer Family Registry. This work was supported by the National Cancer Institute, National Institutes of Health under RFA-CA-06-503 and through cooperative agreements with members of the Breast Cancer Family Registry (BCFR) and Principal Investigators, including Columbia University (U01 CA69398), Fox Chase Cancer Center (U01 CA69631), Huntsman Cancer Institute (U01 CA69446) and Georgetown University Medical Center Informatics Support Center (HHSN261200900010C). This work was also supported by the Breast Cancer Research Foundation.

\section{CONFLICT OF INTEREST}

The authors declare no conflict of interest.

\section{DISCLAIMER}

The content of this manuscript does not necessarily reflect the views or policies of the National Cancer Institute or any of the collaborating centers in the BCFR, nor does mention of trade names, commercial products, or organisations imply endorsement by the US Government or the BCFR.

\section{REFERENCES}

ACS (2012) American Cancer Society. Cancer Facts and Figures 2012. American Cancer Society: Atlanta.

Antoniou AC, Rookus M, Andrieu N, Brohet R, Chang-Claude J, Peock S, Cook M, Evans DG, Eeles R, Nogues C, Faivre L, Gesta P, van Leeuwen FE, Ausems MG, Osorio A, Caldes T, Simard J, Lubinski J, Gerdes AM, Olah E, Furhauser C, Olsson H, Arver B, Radice P, Easton DF, Goldgar DE (2009) Reproductive and hormonal factors, and ovarian cancer risk for BRCA1 and BRCA2 mutation carriers: results from the International BRCA1/2 Carrier Cohort Study. Cancer Epidemiol Biomarkers Prev 18(2): 601-610.

Buys SS, Partridge E, Black A, Johnson CC, Lamerato L, Isaacs C, Reding DJ, Greenlee RT, Yokochi LA, Kessel B, Crawford ED, Church TR, Andriole GL, Weissfeld JL, Fouad MN, Chia D, O’Brien B, Ragard LR, Clapp JD, Rathmell JM, Riley TL, Hartge P, Pinsky PF, Zhu CS, Izmirlian G, Kramer BS, Miller AB, Xu JL, Prorok PC, Gohagan JK, Berg CD (2011) Effect of screening on ovarian cancer mortality: the Prostate, Lung, Colorectal and Ovarian (PLCO) Cancer Screening Randomized Controlled Trial. JAMA 305(22): 2295-2303.

Chan LM, Westhoff CL (2010) Tubal sterilization trends in the United States. Fertil Steril 94(1): 1-6.

Cibula D, Zikan M, Dusek L, Majek O (2011) Oral contraceptives and risk of ovarian and breast cancers in BRCA mutation carriers: a meta-analysis. Expert Rev Anticancer Ther 11(8): 1197-1207.

Collaborative Group on Epidemiological Studies of Ovarian Cancer, Beral V, Doll R, Hermon C, Peto R, Reeves G (2008) Ovarian cancer and oral contraceptives: collaborative reanalysis of data from 45 epidemiological studies including 23,257 women with ovarian cancer and 87,303 controls. Lancet 371(9609): 303-314.

Crum CP, Drapkin R, Miron A, Ince TA, Muto M, Kindelberger DW, Lee Y (2007) The distal fallopian tube: a new model for pelvic serous carcinogenesis. Curr Opin Obstet Gynecol 19(1): 3-9.

Delgado-Cruzata L, Wu HC, Perrin M, Liao Y, Kappil MA, Ferris JS, Flom JD, Yazici H, Santella RM, Terry MB (2012) Global DNA methylation levels in white blood cell DNA from sisters discordant for breast cancer from the New York site of the Breast Cancer Family Registry. Epigenetics 7(8): 868-874.

Gronwald J, Byrski T, Huzarski T, Cybulski C, Sun P, Tulman A, Narod SA, Lubinski J (2006) Influence of selected lifestyle factors on breast and ovarian cancer risk in BRCA1 mutation carriers from Poland. Breast Cancer Res Treat 95(2): 105-109.

Gwinn ML, Lee NC, Rhodes PH, Layde PM, Rubin GL (1990) Pregnancy, breast feeding, and oral contraceptives and the risk of epithelial ovarian cancer. J Clinl Epidemiol 43(6): 559-568.

Harlow SD, Linet MS (1989) Agreement between questionnaire data and medical records. The evidence for accuracy of recall. Am J Epidemiol 129(2): 233-248.

Hyman DM, Spriggs DR (2012) Unwrapping the implications of BRCA1 and BRCA2 mutations in ovarian cancer. JAMA 307(4): 408-410.

Iodice S, Barile M, Rotmensz N, Feroce I, Bonanni B, Radice P, Bernard L, Maisonneuve P, Gandini S (2010) Oral contraceptive use and breast or ovarian cancer risk in BRCA1/2 carriers: a meta-analysis. Eur J Cancer 46(12): 2275-2284.

John EM, Hopper JL, Beck JC, Knight JA, Neuhausen SL, Senie RT, Ziogas A, Andrulis IL, Anton-Culver H, Boyd N, Buys SS, Daly MB, O’Malley FP, Santella RM, Southey MC, Venne VL, Venter DJ, West DW, Whittemore AS, Seminara D (2004) The Breast Cancer Family Registry: an infrastructure for cooperative multinational, interdisciplinary and translational studies of the genetic epidemiology of breast cancer. Breast Cancer Res 6(4): R375-R389.

Kennedy DO, Agrawal M, Shen J, Terry MB, Zhang FF, Senie RT, Motykiewicz G, Santella RM (2005) DNA repair capacity of lymphoblastoid cell lines from sisters discordant for breast cancer. J Natl Cancer Inst 97(2): 127-132.

Machella N, Terry MB, Zipprich J, Gurvich I, Liao Y, Senie RT, Kennedy DO, Santella RM (2008) Double-strand breaks repair in lymphoblastoid cell lines from sisters discordant for breast cancer from the New York site of the BCFR. Carcinogenesis 29(7): 1367-1372.

McDonald JA, Goyal A, Terry MB (2013) Alcohol intake and breast cancer risk: weighing the overall evidence. Curr Breast Cancer Rep 5: 208-221.

McGuire V, Felberg A, Mills M, Ostrow KL, DiCioccio R, John EM, West DW, Whittemore AS (2004) Relation of contraceptive and reproductive history 
to ovarian cancer risk in carriers and noncarriers of BRCA1 gene mutations. Am J Epidemiol 160(7): 613-618.

McGuire V, John EM, Felberg A, Haile RW, Boyd NF, Thomas DC, Jenkins MA, Milne RL, Daly MB, Ward J, Terry MB, Andrulis IL, Knight JA, Godwin AK, Giles GG, Southey M, West DW, Hopper JL, Whittemore AS, kConFab I (2006) No increased risk of breast cancer associated with alcohol consumption among carriers of BRCA1 and BRCA2 mutations ages $<50$ years. Cancer Epidemiol Biomarkers Prev 15(8): 1565-1567.

McLaughlin JR, Risch HA, Lubinski J, Moller P, Ghadirian P, Lynch H, Karlan B, Fishman D, Rosen B, Neuhausen SL, Offit K, Kauff N, Domchek S, Tung N, Friedman E, Foulkes W, Sun P, Narod SA (2007) Reproductive risk factors for ovarian cancer in carriers of BRCA1 or BRCA2 mutations: a case-control study. Lancet Oncol 8(1): 26-34.

Modan B, Hartge P, Hirsh-Yechezkel G, Chetrit A, Lubin F, Beller U, Ben-Baruch G, Fishman A, Menczer J, Struewing JP, Tucker MA, Wacholder S (2001) Parity, oral contraceptives, and the risk of ovarian cancer among carriers and noncarriers of a BRCA1 or BRCA2 mutation. $N$ Engl J Med 345(4): 235-240.

Narod SA, Risch H, Moslehi R, Dorum A, Neuhausen S, Olsson H, Provencher D, Radice P, Evans G, Bishop S, Brunet JS, Ponder BA (1998) Oral contraceptives and the risk of hereditary ovarian cancer. Hereditary Ovarian Cancer Clinical Study Group. N Engl J Med 339(7): 424-428.

Negri E, Franceschi S, Tzonou A, Booth M, La Vecchia C, Parazzini F, Beral V, Boyle P, Trichopoulos D (1991) Pooled analysis of 3 European case-control studies: I. Reproductive factors and risk of epithelial ovarian cancer. Int J Cancer 49(1): 50-56.

Neuhausen SL, Ozcelik H, Southey MC, John EM, Godwin AK, Chung W, Iriondo-Perez J, Miron A, Santella RM, Whittemore A, Andrulis IL, Buys SS, Daly MB, Hopper JL, Seminara D, Senie RT, Terry MB (2009) BRCA1 and BRCA2 mutation carriers in the Breast Cancer Family Registry: an open resource for collaborative research. Breast Cancer Res Treat 116(2): 379-386.

Oakley D, Sereika S, Bogue EL (1991) Oral contraceptive pill use after an initial visit to a family planning clinic. Fam Plan Perspect 23(4): 150-154.

Pal T, Permuth-Wey J, Betts JA, Krischer JP, Fiorica J, Arango H, LaPolla J, Hoffman M, Martino MA, Wakeley K, Wilbanks G, Nicosia S, Cantor A, Sutphen R (2005) BRCA1 and BRCA2 mutations account for a large proportion of ovarian carcinoma cases. Cancer 104(12): 2807-2816.

Ramus SJ, Harrington PA, Pye C, DiCioccio RA, Cox MJ, Garlinghouse-Jones K, Oakley-Girvan I, Jacobs IJ, Hardy RM, Whittemore AS, Ponder BA, Piver MS, Pharoah PD, Gayther SA (2007) Contribution of BRCA1 and BRCA2 mutations to inherited ovarian cancer. Hum Mutat 28(12): 1207-1215.

Reitsma W, de Bock GH, Oosterwijk JC, Bart J, Hollema H, Mourits MJ (2012) Support of the 'fallopian tube hypothesis' in a prospective series of riskreducing salpingo-oophorectomy specimens. Eur J Cancer 49(1): 132-141.

Rice LW (2010) Hormone prevention strategies for breast, endometrial and ovarian cancers. Gynecol Oncol 118(2): 202-207.

Risch HA, Marrett LD, Howe GR (1994) Parity, contraception, infertility, and the risk of epithelial ovarian cancer. Am J Epidemiol 140(7): 585-597.

Runnebaum IB, Wang-Gohrke S, Vesprini D, Kreienberg R, Lynch H, Moslehi R, Ghadirian P, Weber B, Godwin AK, Risch H, Garber J, Lerman C, Olopade OI, Foulkes WD, Karlan B, Warner E, Rosen B, Rebbeck T, Tonin P, Dube MP, Kieback DG, Narod SA (2001) Progesterone receptor variant increases ovarian cancer risk in BRCA1 and BRCA2 mutation carriers who were never exposed to oral contraceptives. Pharmacogenetics 11(7): 635-638.

Russo A, Calo V, Bruno L, Rizzo S, Bazan V, Di Fede G (2009) Hereditary ovarian cancer. Crit Rev Oncol Hematol 69(1): 28-44.

Salvador S, Gilks B, Kobel M, Huntsman D, Rosen B, Miller D (2009) The fallopian tube: primary site of most pelvic high-grade serous carcinomas. Int J Gynecol Cancer 19(1): 58-64.

Shen J, Terry MB, Gurvich I, Liao Y, Senie RT, Santella RM (2007) Short telomere length and breast cancer risk: a study in sister sets. Cancer Res 67(11): 5538-5544.

Shen J, Terry MB, Liao Y, Gurvich I, Wang Q, Senie RT, Santella RM (2012) Genetic variation in telomere maintenance genes, telomere length and breast cancer risk. PLoS One 7(9): e44308.

Spangler L, Grafton J, Ichikawa L, Lacroix A, Ott S, Hubbard R, Operskalski B, Anderson J, Kratohvil C, Endres J, Rillamas-Sun E, Scholes D (2012) PS2-29: Comparison of self-reported oral contraceptive use and automated prescription fills. Clin Med Res 10(3): 186-187.

Stratton JF, Pharoah P, Smith SK, Easton D, Ponder BA (1998) A systematic review and meta-analysis of family history and risk of ovarian cancer. $\mathrm{Br} J$ Obstet Gynaecol 105(5): 493-499.

Terry MB, Knight JA, Zablotska L, Wang Q, John EM, Andrulis IL, Senie RT, Daly M, Ozcelik H, Briollais L, Santella RM (2007) Alcohol metabolism, alcohol intake, and breast cancer risk: a sister-set analysis using the Breast Cancer Family Registry. Breast Cancer Res Treat 106(2): 281-288.

Whittemore AS, Balise RR, Pharoah PD, Dicioccio RA, Oakley-Girvan I, Ramus SJ, Daly M, Usinowicz MB, Garlinghouse-Jones K, Ponder BA, Buys S, Senie R, Andrulis I, John E, Hopper JL, Piver MS (2004) Oral contraceptive use and ovarian cancer risk among carriers of BRCA1 or BRCA2 mutations. Br J Cancer 91(11): 1911-1915.

Whittemore AS, Harris R, Itnyre J (1992) Characteristics relating to ovarian cancer risk: collaborative analysis of 12 US case-control studies. II. Invasive epithelial ovarian cancers in white women. Collaborative Ovarian Cancer Group. Am J Epidemiol 136(10): 1184-1203.

Wu HC, Delgado-Cruzata L, Flom JD, Kappil M, Ferris JS, Liao Y, Santella RM, Terry MB (2011) Global methylation profiles in DNA from different blood cell types. Epigenetics 6(1): 76-85.

Wu HC, Delgado-Cruzata L, Flom JD, Perrin M, Liao Y, Ferris JS, Santella RM, Terry MB (2012) Repetitive element DNA methylation levels in white blood cell DNA from sisters discordant for breast cancer from the New York site of the Breast Cancer Family Registry. Carcinogenesis 33(10): 1946-1952.

Yazici H, Terry MB, Cho YH, Senie RT, Liao Y, Andrulis I, Santella RM (2009) Aberrant methylation of RASSF1A in plasma DNA before breast cancer diagnosis in the Breast Cancer Family Registry. Cancer Epidemiol Biomarkers Prev 18(10): 2723-2725.

Zipprich J, Terry MB, Liao Y, Agrawal M, Gurvich I, Senie R, Santella RM (2009) Plasma protein carbonyls and breast cancer risk in sisters discordant for breast cancer from the New York site of the Breast Cancer Family Registry. Cancer Res 69(7): 2966-2972.

This work is published under the standard license to publish agreement. After 12 months the work will become freely available and the license terms will switch to a Creative Commons AttributionNonCommercial-Share Alike 3.0 Unported License. 